\title{
Perlindungan Hukum Terhadap Buruh Perempuan Pada Malam Hari
}

\section{. Mukmin Zakie}

\begin{abstract}
Abstrak.
Both Act No.13 on the year of 2003 and the Ministery Degree No. 244 on the Year 2003 have already regulated the protection of female workers in the night. Act No.13 on the Year 2003 emphasizes sanction if there is infrigements.
\end{abstract}

\section{Pendahuluan}

Pekerjaan mempunyai makna yang sangat penting dalam kehidupan manusia sehingga setiap orang membutuhkan pekerjaan. Pekejjaan dapat dimaknai sebagai sumber penghasilan. seseorang untuk memenuhi kebutuhan hidup bagi dirinya sendiri dan keluarganya. Dapat juga dimaknai sebagai sarana untuk mengaktualisasikan diri sehingga seseorang merasa hidupnya menjadi lebih berharga baik bagi dirinya, keluarganya maupun lingkungannya, oleh karena itu hak atas pekerjaan merupakan hak azasi yang melekat pada diri seseorang yang wajib dijunjung tinggi dan dihormati.

Makna dan arti pentingnya pekerjaan bagi setiap orang tercermin dalam UndangUndang Dasar Negara Republik Indonesia Tahun 1945 Pasal 27 ayat (2) menyatakan bahwa setiap Warga Negara Republik Indo- nesia berhak atas pekerjaan dan penghidupan yang layak bagi kemanusiaan. ${ }^{1}$

Pembangunan ketenagakerjaan sebagai bagian integral dari pembangunan nasional berdasarkan Pancasila dan Undang-undang Dasar Negara Republik Indonesia Tahun 1945, dilaksanakan dalam rangka pembangunan manusia Indonesia seutuhnya untuk meningkatkan harkat, martabat, dan harga diri tenaga kerja serta mewujudkan masyarakat sejahtera, adil, makmur, dan merata, baik materiil maupun spiritual.

Oleh karena itu, diharapkan tenaga kerja dapat melaksanakan fungsinya dengan baik melalui pemberian kesempatan kerja yang merata, baik itu kepada perempuan atau kepada laki-laki, perlindungan hak-haknya dalam menjalankan pekerjaan terutama dalam hal pemberian jaminan kesejahteraan, kesehatan, keselamatan, dan semua aspek-

1 Penjelasan Umum Undang-Undang Nomor 39 Tahun 2004 tentang Penempatan Dan Perlindungan Tenaga Kerja Indonesia Di Luar Negeri. 
aspek dalam bidang ketenagakerjaan. Pembangunan ketenagakerjaan harus diatur sedemikian rupa sehingga terpenuhi hak-hak dan perlindungan yang mendasar bagi tenaga kerja dan pekerjalburuh serta pada saat yang bersamaan dapat mewujudkan kondisi yang kondusif bagi pengembangan dunia usaha.

Selain itu bentuk perhatian pemerintah terhadap masalah ketenagakerjaan juga terbukti dengan dikeluarkannya berbagai peraturan perundang-perundangan tentang ketenagakerjaan atau perburuhan, termasuk meratifikasi konvensi-konvensi organisasi perburuhan internasional (ILO). Peraturan perundang-perundangan yang dikeluarkan pemerintah tersebut bertujuan untuk memberikan perlindungan terhadap tenaga kerja, diantaranya perlindungan untuk memperoleh kesempatan kerja, menjamin hak-hak dasar tenaga kerja, keselamatan dan kesehatan kerja serta perlindungan terhadap tenaga kerja sehingga tercipta rasa aman, tenteram, sejahtera lahir dan batin bagi tenaga kerja maupun keluarga.

Perlindungan tenaga kerja mempunyai tujuan agar majikan tidak berbuat semenamena terhadap buruh/tenaga kerja di dalam buruh melakukan pekerjaan terutama dalam hal mempekerjakan buruh perempuan.

Buruh perempuan dalam hal ini mempunyai resiko besar yang harus ditanggung oleh pengusaha/majikan yang memperkerjakan pada malam hari. Undang-undang memberikan batasan kepada buruh perempuan untuk tidak melakukan pekerjaan pada keadaan, tempat, dan waktu-waktu tertentu. Pembatasan ini sehubungan dengan kondisi perempuan secara kodrati berbeda dengan pria, terhadap pembatasan melakukan pekerjaan bagi perempuan, Iman Soepomo berpendapat bahwa:

Pada prinsipnya wanita diperbolehkan menjalankan semua pekerjaan, hanya saja dalam hal-hal tertentu diberi pembatasan. Pertimbangan untuk membatasi pekejjaan wanita adalah bahwa wanita itu lemah badannya untuk menjaga kesehatan dan kesusilaannya. Soal kesusilaan mungkin lebih erat dengan perasaan yang halus daripada kelemahan badan yang mengurangkan kemampuan membela diri dari bahaya serangan fisik dan asusila. Kedua soal ini yaitu kelemahan badan dan kehalusan perasaan wanita memang perlu diselidiki dalam hubungannya dengan menjalankan pekerjaan. ${ }^{2}$

$\mathrm{Di}$ antara perusahaan-perusahaan yang banyak memakai buruh perempuan pada malam hari ialah perusahaan tempat hiburan seperti: bioskop, kafe, diskotik dan arena-arena ketangkasan yang umumnya buka sampai tengah malam bahkan ada yang sampai dini hari. Tempat-tempat hiburan ini diasumsikan tidak akan ramai apabila tidak ada pekerja perempuan, dilain sisi pekerjaan itu memudahkan adanya perbuatan asusila termasuk diantaranya pelecehan seksual meskipun semua itu bagi sebagian pekerja perempuan dihindari karena tujuan mereka adalah bekejja untuk mendapatkan upah demi keluarganya.

Ada sebuah keadaan yang dilematis, disatu sisi bekeja adalah hak yang sama-sama bisa diraih oleh laki-laki maupun perempuan, namun disisi lain untuk keadaan tertentu, dalam

${ }^{2}$ Iman Soepomo, Hukum Perburuhan Bidang Kesehatan Kerja, (PT. Pradnya Paramita, Jakarta, 1988). HIm. 55 
hal ini adalah bekerja sampai dengan malam hari perempuan dipandang memiliki keadaan yang berbeda. Nilai-nilai dan juga norma kesusilaan menjadikan perempuan nampak tidak terhormat dan apabila memaksakan bekerja pada malam hari. Hal lainnya adalah juga dipandang membahayakan diri sendiri, dimana perempuan cenderung lebih rentan mengalami gangguan fisik maupun psikis terkait dengan masalah keamanan perjalanan kerja dan juga kesehatan pekerja perempuan.

Diterbitkannya Undang-Undang Nomor 13 tahun 2003 tentang Ketenagakerjaan (UU No.13/2003) oleh Pemerintah juga berdasarkan pertimbangan bahwa banyak perusahaanperusahaan yang jenis pekerjaan, menurut sifat, tempat dan keadaan seharusnya dilakukan oleh buruh perempuan pada malam hari, maka ditetapkan Peraturan Menteri Tenaga Kerja RI : NOMOR KEP.244/MEN/2003 TAHUN 2003 tentang Kewajiban Pengusaha yang Mempekerjakan Pekerja/ Buruh Perempuan Antara Pukul 23.00 sampai Degan 07.00.

Adanya Peraturan Menteri ini seolah-olah telah menjawab semua permasalahan mengenai perlindungan hukum terhadap pekerja perempuan yang bekerja pada malam hari. Keadaan kondusif bagi buruh perempuan yang bekerja di malam hari diharapkan dapat tercipta. Namun kemudian hal yang perlu dilihat lebih dalam adalah sejauh manakah UU No.13/ 2003 maupun Peraturan Menteri Tenaga Kerja RI : NOMOR KEP.244/MEN/2003 ini memberikan perlindungan hukum kepada buruh perempuan pada malam hari, kemudian sebagai jaminan penegakan hukum, sanksi atau hukuman yang seperti apa yang dapat dikenakan pada pihak pengusaha yang pengaturan atas perlindungan hukum tersebut.

\section{Buruh Laki-laki dan Buruh Perempuan}

Terminologi buruh berdasarkan UU No.13/2003 disama artikan dengan kata "pekerja" yang maksudnya adalah setiap orang yang bekerja dengan menerima upah atau imbalan dalam bentuk lain (UU No.13/ 2003 Pasal 1 Ayat 3). Selanjutnya tidak ada pembedaan antara apa yang disebut dengan buruh laki-laki dan buruh perempuan. Pembedaan antara laki-laki dan perempuan dalam wacana gender umumnya merupakan pembedaan tugas dan peran sosial laki-laki dan perempuan berdasarkan harapan, kebiasaan, adat dan tradisi yang melekat pada kebudayaan suatu masyarakat. Sebagai gambaran, sebagian besar juga karena kodrat biologis yang melekat pada laki-laki dan perempuan pada kebanyakan pandangan masyarakat menghasilkan pembedaan yang dipetakan sebagai berikut: ${ }^{3}$

\section{Tabel 1}

\section{Karakteristik sifat ruang lingkup kerja}

\begin{tabular}{|c|c|c|}
\hline $\begin{array}{l}\text { Aspek yang } \\
\text { dibedakan }\end{array}$ & Perempuan & Lakj-laki \\
\hline $\begin{array}{l}\text { Karakteristik sifat } \\
\text { Ruang lingkup }\end{array}$ & $\begin{array}{l}\text { Feminim } \\
\text { Domestik }\end{array}$ & $\begin{array}{l}\text { Maskulin } \\
\text { Publik }\end{array}$ \\
\hline Fungsi & $\begin{array}{l}\text { Pencari nafkah } \\
\text { tambahan }\end{array}$ & $\begin{array}{l}\text { Pencari } \\
\text { nafkah utama }\end{array}$ \\
\hline Stereotip kerja & kerja feminim & $\begin{array}{l}\text { Kerja } \\
\text { maskulin }\end{array}$ \\
\hline $\begin{array}{l}\text { Pembagian kerja } \\
\text { gender }\end{array}$ & $\begin{array}{l}\text { Reprod uktif } \\
\text { (mengasuh anak, } \\
\text { mengurus rumah } \\
\text { tangga dan } \\
\text { sebagainya) }\end{array}$ & $\begin{array}{l}\text { Produktif } \\
\text { (kerja yang } \\
\text { menghasikan } \\
\text { uang) }\end{array}$ \\
\hline
\end{tabular}

${ }^{3}$ Eli Nur Hayati, Panduan Untuk Pendampingan Perempuan Korban Kekerasan, Konseling Berwawasan Gender, (RifkaAnnisa, Yogyakarta, 2000). HIm. 25. 
Fungsi Stereotip kerjaPembagian kerja gender Feminim Domestik Pencari nafkah tambahan Kerja feminim Reproduktif (mengasuh anak, mengurus rumah tangga dan sebagainya) MaskulinPublikPencari nafkah utamaKerja maskulin Produktif (kerja yang menghasilkan uang).

Konstruksi budaya tersebut dalam suatu frame berpikir masyarakat sewaktu-waktu berdasarkan masa (waktu), daerah dan adat juga tradisi dapat berubah. Oleh karena itu perempuan bekerja dewasa ini bukan_suatu permasalahan lagi. namun demikian masih tetap ada nilai-nilai dan norma kesusilaan yang melindungi keberadaan aktifitas buruh perempuan dengan peraturan perundangan sebagai wujud dari perlindungan hukum.

\section{Hubungan antara Tenaga Kerja dan Pengusaha}

Secara umum hukum ketenagakerjaan merupakan himpunan peraturan yang pada pokoknya mengatur hubungan antara tenaga kerja dan pengusaha, antara tenaga kerja dengan tenaga kerja dan antara tenaga kerja dengan penguasa (pemerintah), termasuk di dalamnya proses-proses dan keputusan yang dikeluarkan untuk merealisasikan hubungan tersebut menjadi kenyataan yang bertujuan untuk mencapai keadilan sosial dalam bidang ketenagakerjaan unituk melindungi tenaga kerja terhadap kekuasaan yang tidak terbatas dari penguasa (pemerintah).

Di dalam UU No. 13 Tahun 2003 pengertian tenaga kerja telah diatur daiam Pasal 1 ayat (2) yakni; setiap orang yang mampu melakukan pekerjaan guna menghasilkan barang dan/atau jasa baik untuk memenuhi kebutuhan sendiri maupun untuk masyarakat. Orang yang melakukan pekerjaan disebut pekerja, sedangkan pengertian pekerja adalah; setiap orang yang bekerja dengan menerima upah atau imbalan dalam bentuk lain, ayat (3).

Sedangkan pengertian pemberi kerja disebutkan dalam pasal yang sama ayat (4) yaitu; orang perseorangan, pengusaha, badan hukum, atau badan-badan lainnya yang memperkerjakan tenaga kerja dengan membayar upah atau imbalan dalam bentuk lain.

Di dalam menjalankan pekerjaan, tenaga kerja tentunya melakukan suatu kerjasama atau ikatan dengan orang lain yang disebut pengusaha yang selanjutnya dapat disebut sebagai hubungan kerja. Hubungan kerja adalah hubungan antara pengusaha dengan pekerja/buruh berdasarkan perjanjian kerja, yang mempunyai unsur pekerjaan, upah, dan perintah. Hubungan kerja terjadi apabila telah terjadi perjanjian kerja antara pengusaha dan pekerja/buruh. Sedangkan yang dimaksud dengan Perjanjian Kerja adalah perjanjian antara pekerja/buruh dengan pengusaha atau pemberi kerja yang memuat syarat-syarat kerja, hak, dan kewajiban para pihak. Menurut Imam Soepomo, ada 2 hal yang penting dalam kaitannya antara tenaga kerja dengan pengusaha, yaitu: 4

"Secara yuridis, tenaga kerja adalah "bebas" karena prinsip negara kita adalah bahwa tidak ada seorangpun boleh diperbudak atau diperhamba, perbudakan, perdagangan budak dan penghambaan

${ }^{4}$ Imam Soepomo, Hukum Perburuhan Undang-undang Dan Peraturan, (Pradnya Paramita, Jakarta, 1983), him. 3 
dan segala perbuatan berupa apapun juga bertujuan kepada itu dilarang. Sedangkan secara sosiologis, tenaga kerja adalah tidak bebas sebagai orang yang tidak mempunyai bekal hidup lain dari pada tenaga kerja itu, ia terpaksa bekerja untuk orang lain dan pengusaha inilah yang pada dasarnya menentukan syarat-syarat kerja itu."

Adapun dalam membuat perjanjian kerja dalam suatu hubungan kerja pada dasarnya meliputi hal-hal penting sebagai berikut: ${ }^{5}$

1. Pembuatan perjanjian kerja karena merupakan titik tolak adanya suatu hubungan kerja;

2. Kewajiban buruh melakukan pekerjaan pada atau dibawah pimpinan pengusaha, yang sekaligus merupakan hak pengusaha atas pekerjaan dari buruh;

3. Kewajiban pengusaha membayar upah kepada buruh, sekaligus merupakan hak buruh atas upah;

4. Berakhirnya hubungan kerja dan;

5. Caranya perselisihan antara pihak-pihak yang bersangkutan diselesaikan dengan sebaik-baiknya.

Adanya perjanjian kerja tersebut memiliki kebermanfaatan dan pengaruh sebagai berikut: 6

1. Meniadakan atau mengurangi hambatanhambatan bagi proses pembangunan yang sedang kita laksanakan sehingga akan terciptanya suatu ketenangan kerja dan adanya jaminan akan kepastian hak dan kewajiban, baik bagi buruh maupun pengusaha.

2. Membantu tercapainya kenaikan prestasi kerja dan mengurangi kemungkinan timbulnya perselisihan serta mempertinggi semangat kerja.

3. Terjadi hubungan kerja yang serasi antara buruh dengan pengusaha.

4. Mencerminkan adanya pelaksanaan demokrasi di perusahaan.

Akibat yang timbul manakala pihak pekerja/buruh dengan pihak majikan telah menandatangani perjanjian kerja adalah adanya hak dan kewajiban masing-masing. Di samping itu kedua belah pihak harus mentaati hal-hal yang diatur di dalam undangundang yang berkaitan dengan hubungan kerja ini, seperti :

\section{Waktu Kerja}

Pengaturan waktu kerja menurut UU No.13 Tahun 2003 tentang Ketenagakerjaan pada Pasal 77 ayat (2) meliputi:

a. 7 (tujuh) jam 1 (satu) hari dan 40 (empat puluh) jam 1(satu) minggu untuk 6 (enam) hari kerja dalam 1 (satu) minggu; atau

b. 8 (delapan) jam 1 (satu) hari dan 40 (empat puluh) jam 1 (satu) minggu untuk 5 (lima) hari masa kerja dalam 1 (satu) minggu.

Tetapi peraturan tersebut dapat disimpangi atau bisa saja tidak dilaksanakan asalkan sudah mendapat izin dari Kepala Dinas Tenaga Kerja dan Transmigrasi atau pegawai yang ditunjuk oleh negara ataupun dapat izin dari Departemen tenaga kerja setempat.

${ }^{5}$ Halili Toha \&, Hari Pramono, Hubungan Kerja antara Majikan dan Buruh, (Rineka Cipta, Jakarta, 1991, Cetakan kedua). HIm.12.

${ }^{6}$ F.X.Djumaldji \& Wiwoho Soejono, Perjanjian Perburuhan dan Hubungan Perburuhan Pancasila, (Bina Aksara, Jakarta, Cetakan ketiga, 1987).HIm.67-68 
Waktu kerja di sini erat kaitannya dengan waktu istirahat. Seperti yang tertuang dalam UU No.13 Tahun 2003 Pasal 79 yang menyatakan bahwa pengusaha wajib memberikan waktu istirahat dan cuti kepada pekerja. Mengenai pengaturan istirahat dan cuti meliputi:

a. Istirahat antara jam jeda, sekurangkurangnya setengah jam setelah bekerja selama 4 (empat) jam terus-menerus dan waktu istirahat itu tidak termasuk jam kerja.

b. Istirahat mingguan 1 hari untuk 6 hari kerja dalam satu minggu atau dua hari untuk lima hari kerja dalam satu minggu.

c. Cuti tahunan, sekurang-kurangnya 12 hari kerja setelah pekerja yang berșangkutan berkerja selama 12 bulan secara terusmenerus, dan

d. Istirahat panjang sekurang-kurangnya 2 bulan dan dilaksanakan pada tahun ketujuh dan kedelapan masing-masing satu bulan bagi pekerja yang telah bekerja selama 6 tahun secara terus menerus pada perusahaan yang sama dengan ketentuan buruh tersebut tidak berhak lagi atas istirahat tahunan dalam 2 tahun berjalan dan selanjutnya berlaku untuk setiap kelipatan masa kerja 6 tahun.

\section{Upah}

Dalam Peraturan Pemerintah No.8 tahun 1981 tentang Perlindungan Upah disebutkan bahwa upah adalah suatu penerimaan sebagai imbalan dari pengusaha kepada buruh untuk melakukan pekerjaan atau jasa yang telah atau akan dilakukan, dinyatakan atau dinilai dalam bentuk uang yang ditetapkan menurut persetujuan atau peraturan perundang-undangan yang berlaku dan dibayarkan atas dasar suatu perjanjian kerja antara pengusaha dengan pekerja, termasuk tunjangan, baik untuk pekerja itu sendiri maupun keluarganya. ${ }^{7}$

Pemberian upah yang tidak dalam bentuk uang dibenarkan asal tidak melebihi $25 \%$ dari nilai upah yang seeharusnya diterima. ${ }^{8}$ Imbalan/penghasilan yang diterima oleh pekerja tidak selamanya disebut sebagai upah, karena bisa jadi imbalan itu bukan termasuk dalam komponen upah.

Dalam UU No.13 Tahun 2003 pengaturan mengenai pengupahan diatur terperinci dalam 11 pasal dimulai pada Pasal 88 sampai dengan Pasal 98 . Dalam UU ini dikatakan pada Pasal 88 ayat (3), kebijakan pengupahan yang melindungi pekerja meliputi:

a. Upah minimum;

b. Upah lembur;

c. Upah tidak masuk kerja karena berhalangan;

d. Upah tidak masuk kerja karena melakukan kegiatan lain diluar pekerjaanya;

e. Upah karena menjalankan hak waktu istirahat kerjanya;

f. Bentuk dan cara pembayaran upah

g. Denda dan potongan upah;

h. Hal-hal yang dapat diperhitungkan dengan upah;

i. Struktur dan skala pengupahan yang proposional;

j. Upah untuk pembayaran pesangon; dan

k. Upah untuk perhitungan pajak penghasilan.

Sesuai dengan Pasal 1 ayat (1) Peraturan Menteri Tenaga Kerja Nomor KEP-226/MEN/

${ }^{7}$ Darwan Prints, Hukum Ketenagakerjaan Indonesia, (Citra Aditya Bakti, Bandung, 2000), hlm. 51.

8 Lalu Husni, op cit, hlm.109 
2000 TAHUN 2000 tentang Perubahan beberapa pasal dalam Permenaker 01/MEN/ 1999 tentang Upah Minimum, pengertian upah minimum adalah upah bulanan terendah yang terdiri dari upah pokok termasuk tunjangan tetap. Berdasarkan penetapan upah minimum dilakukan pertimbangan: ${ }^{9}$

1. Kebutuhan Hidup Minimum (KHM);

2. Indeks Harga Konsumen (IHK);

3. Kemampuan, perkembangan dan kelangsungan perusahaan untuk memproduksi suatu barang;

4. Upah pada umumnya berlaku didaerah tertentu dan antar daerah;

5. Kondisi pasar kerja;

6. Tingkat perkembangan perekonomian dan pendapatan perkapita.

Pengusaha wajib membayar upah kepada para pekerjanya secara teratur sejak terjadinya hubungan kerja sampai dengan berakhimya hubungan kerja. Upah yang diberikan oleh pengusaha tidak boleh diskriminasi antara pekerja pria dan pekerja wanita untuk pekerjaan yang sama nilainya.

Menurut Pasal 4 Peraturan Pemerintah No.8 tahun 1981 tentang Perlindungan Upah disebutkan bahwa upah yang tidak dibayar jika buruh/pekerja tidak melakukan pekerjaan, hal ini disebut dengan azas no work no pay, azas ini tidak berlaku mutlak, maksudnya dapat dikesampingkan dalam hal-hal tertentu dengan kata lain pekerja tetap mendapatkan upah meskipun tidak dapat melakukan = pekerjaan.

Pembayaran upah menurut Pasal 10 ayat (1) PP No.8 tahun 1981 harus dibayarkan secara langsung kepada buruh/pekerja yang bersangkutan pada waktu yang telah ditentukan sesuai dengan perjanjian kerja. Upah dibayarkan seminggu sekali atau sebulan sekali, kecuali perjanjian kerja untuk waktu tertentu kurang dari seminggu. Jika pembayaran upah terlambat, menurut Pasal 19 PP No.8 tahun 1981, mulai dari hari keempat sampai hari kedelapan terhitung dari hari dimana upah seharusnya dibayarkan, maka upah harus ditambah $5 \%$ untuk setiap hari keterlambatan. Sesudah hari kedelapan tambahan itu menjadi $1 \%$ untuk setiap keterlambatan dengan ketentuan tambahan untuk satu bulan tidak boleh melebihi $50 \%$ dari upah yang seharusnya dibayarkan. ${ }^{10}$

Mengenai pengaturan tentang upah lembur, dimana dikatakan dalam keadaan tertentu terdapat atau terjadi kondisi tertentu yang mengharuskan buruh/pekerja bekeja lebih dari 7 jam sehari atau 40 jam seminggu, maka jam kerja dapat menyimpang dari ketentuan tersebut, dengan ketentuan kelebihan jam kerja tersebut harus dihitung sebagai lembur. Cara penghitungan upah. lembur telah ditetapkan dalam Keputusan Menteri Tenaga Kerja dan Transmigrasi Nomor Kep.102/MenNi/2004 Tahun 2004 tentang Waktu Kerja Lembur dan Upah Kerja Lembur Komponen upah untuk dasar perhitungan upah lembur terdiri dari upah pokok, tunjangan jabatan; tunjangan kemahalan, nilai pemberian catu untuk karyawan sendiri.

Kewajiban pembayaran upah secara penuh dapat dikecualikan dengan adanya pemotongan terhadap:

a. Ganti rugi kepada pengusaha

${ }_{9}^{9}$ Abdul Khakim, Pengantar Hukum Ketenagakerjaan Indonesia, (PT. Citra Aditya Bakti, Bandung, 2003), $\operatorname{him} 76$

${ }^{10} \mathrm{lbid}, \mathrm{him} 81$ 
b. Denda yang telah disetujui

c. luran yang telah disepakati

d. Sewa rumah, sawah, tanah dan sebagainya yang digunakan oleh pekerja

e. Hutang atau bon dan sebagainya; dengan ketentuan bahwa pemotongan tersebut seluruhnya setiap kali tidak boleh melebihi $25 \%$ dari upah tenaga kerja yang harus diterima

f. Harus dicatat dalam daftar pembayaran upah menurut contoh yang diberikan oleh Departemen Tenaga Kerja.

\section{Dasar Hukum Perlindungan}

Arti penting perlindungan terhadap buruh tidak hanya sebatas demi kemanusiaan saja, tetapi juga untuk pertumbuhan ekonomi pengusaha dan buruh yang diwujudkan dengan dijalankannya fungsi masing-masing atas dasar nilai-nilai bersama dan berdasarkan kesepakatan yang memungkinkan masingmasing pihak mengklaim atas hak-haknya dan kewajiban pihak lain.

Perlindungan hukum terhadap perempuan yang bekerja dimalam hari telah diatur dalam sebuah pembatasan yang diatur di dalam Pasal 76 UU No.13/2003 sebagai berikut:

1. Pekerjal buruh perempuan yang berumur kurang dari 18 (delapan belas) tahun dilarang dipekerjakan antara pukul 23.00 sampai dengan pukul 07.00 .

2. Pengusaha dilarang mempekerjakan pekerja/buruh perempuan hamil yang menurut keterangan dokter berbahaya bagi kesehatan dan keselamatan kandungannya maupun dirinya apabila bekerja antara pukul 23:00 sampai dengan pukul 07.00.

3. Pengusaha yang mempekerjakan pekerja/buruh perempuan antara pukul
23.00 sampai dengan pukul 07.00 wajib:

a. memberikan makanan dan minuman bergizi; dan

b. menjaga kesusilaan dan keamanan selama di tempat kerja.

4. Pengusaha wajib menyediakan angkutan antar jemput bagi pekerjaburuh perempuan yang berangkat dan pulang bekeja antara pukul 23.00 sampai dengan pukul 05.00 .

5. Ketentuan sebagaimana dimaksud dalam ayat (3) dan ayat (4) diatur dengan Keputusan Menteri.

Sebenamya jauh sebelum undang-undang ketenagakerjaan memberikan pembatasan jam kerja terhadap pekerja/buruh wanita, pengaturannya telah ada di dalam Staatsblad Nomor 647 tahun 1925 tentang. Pembatasan Pekerjaan Anak dan Pekerjaan Wanita Pada Malam Hari jo Staatsblad Nomor 45 Tahun 1941 tentang Penetapan Baru yang Berhubungan dengan keja malam untuk wanita.

Staatblads No. 647 tahun 1925 dalam Pasal 3 menyatakan bahwa :

Seorang wanita antara pukul sepuluh malam sampai pukul 5 pagi tidak boleh menjalankan pekerjaan seperti yang termaksud pada ayat pertama dan ayat kedua di atas ini. Sepanjang hal itu tidak ada ijin dari atau berdasarkan surat keputusan pemerintah untuk perusahaan tertentu pada umumnya atau untuk pabrik, tempat kerja atau perusahaan tertentu pada khususnya, dan segala sesuatu yang berhubungan dengan kepentingan khusus dari perusahaan.

\section{Waktu Kerja Malam Hari Bagi Wanita}

Dalam. Undang-undang No.13 Tahun 2003 tentang Hukum Ketenagakerjaan, 
menjelaskan dengan sejelas-jelasnya tata cara bagi pengusaha untuk mempekerjakan pekerja wanita di malam hari. Karena mempekerjakan pekerja wanita pada malam hari memiliki kekhususan yang dimaksud untuk melindungi wanita itu sendiri. Hal tersebut tertuang lengkap pada satu pasal, yaitu pada Pasal 76 yang terdiri dari 5 ayat.

Dalam ayat (1) dikatakan bahwa pekerja wanita yang berumur kurang dari 18. (delapan belas) tahun dilarang mempekerjakan wanita tersebut antara pukul 23.00 sampai dengan 07.00. hal ini dilakukan karena pekerja wanita yang masuk ke dalam kategori di bawah 18 tahun dikatakan kedalam golongan anak-anak.

Untuk masalah wanita yang sedang hamil, dalam ayat (2) Pasal 76 ini menyatakan bahwa pengusaha dilarang atau tidak diperbolehkan mempekerjakan pekerja hamil antara pukul 23.00 sampai dengan 07.00 , yang menurut keterangan dokter berbahaya bagi kesehatan dan keselamatan kandungannya maupun dirinya. Ayat ini dimaksudkan untuk menghindari pekerja wanita yang hamil mengalami gugur kandungan.
Dalam Pasal 76 ayat (3) dan

mewajibkan pengusaha untuk:

a. Memberi makanan dan minuman yang bergizi.

b. Menjaga *kesusilaan dan keamanan selama ditempat kerja.

Pengusaha juga memiliki kewajiban untuk menyediakan angkutan antar jemput bagi pekerja perempuan yang berangkat dan pulang bekerja antara pukul 23.00 sampai dengan 07.00 .

Agar suatu perusahaan dapat memperoleh izin untuk mempekerjakan pekerja wanita pada malam hari maka periu perusahaan tersebut mengajukan izin kepada Dinas Tenaga Kerja dan Transmigrasi setempat. Caranya yaitu dengan meminta formulir permohonan izin rangkap tiga lalu diisi dan diserahkan kepada Kepala Dinas Tenaga Kerja dan Transmigrasi di wilayah perusahaan tersebut berada. Ada beberapa syarat tertentu untuk perusahaan yang akan mempekerjakan pekerja wanita pada malam hari, yaitu:

1. Sifat pekerjaan atau jenis usaha memerlukan kerja terus-menerus, atau;

2. Untuk mencapai target produksi, atau;

3. Untuk memperoleh mutu produksi yang lebih baik bilamana dikerjakan oleh pekerja wanita.

Formulir berisi data-data perusahaan, yaitu:

1. Nama orang yang bertanda tangan.

2. Jabatan dari orang yang bertanda tangan.

3. Nama perusahaan.

4. Alamat perusahan.

5. Jumlah pekerja wanita .

6. Jumlah pekerja pria.

7. Aturan waktu kerja yang ada dalam perusahaan tersebut.

8. Alasan perusahaan mempekerjakan pekerja wanita pada malam hari.

9. Jumlah pekerja wanita yang nantinya akan dipekerjakan pada malam hari secara terperinci menurut bagian-bagian yang ada dalam perusahaan tersebut

10. Hal yang dimohonkan (dalam hal ini izin untuk mempekerjakan pekerja wanita pada malam hari).

11. Jangka waktu kerja pada malam hari yang dimohonkan.

12. Syarat-syarat yang harus diperhatikan untuk perusahaan yang bersangkutan

13. Tanggal, bulan dan tahun ditandatanganinya surat permohonan izin tersebut. 
14. Materai Rp. $6.000,00$ beserta tanda tangan diatasnya.

Dalam izinnya Kepala Dinas Tenaga Kerja dan Transmigrasi memutuskan antara lain:

1. Memberikan izin kepada perusahaan yang bersangkutan atau pimpinan perusahaan untuk mempekerjakan pekerja wanita pada bagian-bagian tertentu dari perusahaan yang bersangkutan.

2. Menetapkan syarat-syarat yang harus ditaati pengusaha yang mempekerjakan pekerja wanita pada malam hari yaitu kesanggupan untuk melindungi dan menjaga keselamatan, kesehatan dan kesusilaannya dalam memenuhi syaratsyarat menurut Peraturan Menteri Tenaga Kerja dan Transmigrasi No. PER-04I MEN/ 1989.

3. Menetapkan jangka waktu izin berlaku, dalam hal ini tidak semua perusahaan yaqng mengajukan izin malam hari bagi pekerja wanita dapat dikabulkan oleh Kepala Dinas Tenaga Kerja dan Transmigrasi setempat. Apabila izin tersebut tidak diberikan maka akan diberikan alasan-alasannya, setelah diketahui alasan-alasan tersebut maka perusahaan yang mengajukan izin tersebut dapat mengajukan kembali setelah memenuhi syarat-syarat yang diminta.

\section{Perlindungan Hukum Terhadap Buruh Perempuan pada Malam hari}

Pengaturan mengenai perlindungan terhadap pekerja perempuan sejatinya telah tercover dalam Undang-undang №.13/2003, dan tata cara bagi pengusaha untuk mempekerjakan pekerja wanita di malam hari. Karena mempekerjakan pekerja wanita pada malam hari memiliki kekhususan yang dimaksud untuk melindungi wanita itu sendiri. Hal tersebut tertuang lengkap pada satu pasal, yaitu pada Pasal 76 yang terdiri dari 5 ayat. Adapun persyaratan-persyaratan bagi perușahaan untuk mempekerjakan wanita pada malam hari, dapat disimpulkan adalah sebagai berikut:

\section{Pekerja wanita tidak dalam keadaan hamil}

Alam telah memperlengkapi wanita untuk melahirkan anak, hanya wanita yang bisa mengandung, memiliki anak dan menyusuinya. Maka seorang wanita yang tengah hamil harus menjaga kesehatannya sendiri dan begitu pula dengan bayi yang dikandungnya. Untuk itu pengusaha tidak boleh mempekerjakan pekerja wanitanya yang sedang hamil apabila menutur keterangan dokter berbahaya bagi kesehatan dan kandungannya sesuai dengan Pasal 76 ayat (2) UU No. 13 Tahun 2003.

\section{Menyediakan angkutan antar jemput}

Untuk memberikan rasa aman dan menjaga keselamatan pekerja wanita maka diperlukan angkutan untuk transportasi para pekerja wanita pada waktu pulang dan berangkat kerja antara pukul 23.00 sampai dengan pukul 07.00 dengan pertimbangan bahwa pulang kerja pada malam hari dan pagi hari sangat rawan bagi keselamatan pekerja wanita itu sendiri. Walaupun demikian hal ini tidaklah menjamin sepenuhnya keamanan dan keselamatannya tetapi minimal dapat mencegah terjadinya tindakan-tindakan kejahatan dijalan pada waktu pulang. Perusahaan dalam hal ini wajib dapat 
memberikan sarana angkutan antar jemput bagi para pekerja wanita.

\section{Memberikan makanan dan minuman bergizi}

Perusahaan diharapkan dapat memberikan fasilitas berupa makanan dan minuman bergizi bagi seorang pekerja wanita yang bekerja pada malam hari, hal ini dimaksudkan agar seorang pekerja wanita dapat selalu menjaga kesehatannya mengingat kerja pada malam hari sebenarnya tidaksesuai dengan kesehatan tubuh yang biasanya pada malam hari tubuh harus istirahat setelah melakukan aktivitas seharian penuh.

Yang dimaksud dengan makanan dan minuman bergizi disini adalah yang mengandung zat-zat yang berguna dan diperlukan oleh tubuh supaya tetap sehat dan merupakan salah satu faktor penunjang di antara faktor-faktor lain dalam mencapai tujuwan keselamatan kerja yang sehat dan produktif dengan efisiensi dan produktivitas kerja yang tinggi.

Dari standar gizi yang ada dalam Departemen Tenaga Kerja dan Transmigrasi, diketahui bahwa yang digunakan sebagai pedoman gizi kerja adalah untuk menyusun jenis dan banyaknya makanan yaitu:

1. Pedoman empat sehat lima sempurna yang terdiri atas:

a. Makanan pokok sumber hidrat arang

b. Lauk pauk sebagai sumber protein.

c. Sayur mayur sebagai sumber vitamin dan mineral.

d. Buah untuk melengkapi vitamin dan mineral.

e. Susu untuk tambahan kesempurnaan nilai gizi
2. pedoman makanan berimbang yaitu kalori yang dibapat dari bahan makanan yang dimakan harus seimbang dengan kalori yang dibutuhkan untuk jenis pekerjaan.

\section{Memperhatikan kebiasaan setempat}

Perusahaan diwajibkan untuk menyesuaikan diri dengan kebiasaan masyarakat setempat dalam hal mempekerjakan pekerja wanita pada malam hari, apakah sesuai dengan normanorma masyarakat dimana perusahaan tersebut berada . Apabila dilihat dari sisi persamaan kedudukan antara pria dan wanita (gender) hal ini sangatlah bertentangan. Seorang wanita berhak bekerja dimana saja, kapan saja, dan apapun pekerjaannya asalkan pekerjaan itu sesuai dengan norma-norma yang ada dalam masyarakat dan tidak bertentangan dengan hukum serta wanita itu sendiri mau dan mampu melakukannya.

Dalam masyarakat Indonesia yang cenderung patriakal, seorang wanita bekerja di malam hari dipandang tidak sesuai dengan kebiasaan dan norma-norma masyarakat setempat. Oleh karena itu untuk menghindari pertentangan yang ada dalam masyarakat, perusahaan itu perlu untuk memperhatikan kebiasaan masyarakat setempat atau paling tidak memberitahukan mengenai jenis pekerjaan apa yang dilakukan oleh perusahaan tersebut.

Setiap pekerja wanita yang bekerja dimalam hari secara tegas telah dilindungi oleh undang-undang dan peraturan-peraturan yang berlaku. Lembaga pengawasan perburuhan merupakan suatu lembaga yang mempunyai wewenang untuk melaksanakan tugas tersebut.

Lembaga ini tidak mengawasi tentang pelaksanaan undang-undang dan peraturan 
perburuhan tetapi juga menggusur hal-hal yang dikenakan hukuman, mengetahui dan menyelami tentang kebutuhan dan keinginan masyarakat akan adanya undang-undang atau peraturan pemerintah dalam suatu hal yang selanjutnya mengumpulkan bahan keterangan agar dapat melaksanakan peraturan perundangan dengan tepat dan benar sehingga hak-hak buruh dapat terlindungi dengan baik dan dapat meningkatkan taraf hidup dari buruh itu sendiri.

Terkait dengan fungsi penegakan hukum, sanksi atau hukuman melengkapi ketentuan mengenai perlindungan hukum terhadap buruh perempuan yang bekerja di malam hari adalah diatur dalam UU No.13/2003 Pasal 187. Dimana pelanggaran atas Pasal ini dikenakan saksi pidana paling lama dua belas (12) bulan dan/ atau denda paling sedikit sepuluh juta rupiah (Rp.10.000.000,-) dan paling banyak seratus juta rupiah (Rp.100.000.000).

\section{Simpulan}

Baik UU No.13/2003 maupun Peraturan Menteri Tenaga Kerja Rl : No. KEP.244/MEN/ 2003 keduanya telah mengatur perihal perlindungan hukum terhadap buruh perempuan yang bekerja pada malam hari dengan menerapkan syarat sebagai berikut :

1. Pekerja wanita tidak dalam keadaan hamil.

2. Menyediakan angkutan antar jemput.

3. Memberikan makanan dan minuman bergizi.

4. Memperhatikan kebiasaan setempat

UU No.13/2003 menekankan adanya sanksi apabila terdapat pelanggaran atas ketentuan tersebut guna pencapaian dari pelaksanaan perlindungan hukum terhadap buruh perempuan pada malam hari. Meskipun demikian, pencapaian tertinggi dari perlindungan hukum ini sesungguhnya adalah rasa keadilan bagi semua pihak, baik bagi pengusaha maupun bagi buruh. Namun demikian, rasa keadilan tidak mesti dapat diraih dengan seperangkat peraturan perundangan yang rigid. Hal ini dikarenakan ada beberapa faktor lain yang mempengaruhi pemenuhan perlindungan hukum ini.

\section{Daftar Pustaka}

Abdul Khākim, 2003. Pengantar Hukum Ketenagakerjaan Indonesia, PT. Citra

- Aditya Bakti, Bandung.

Darwan Prints, 2000. Hukum Ketenagakerjaan Indonesia, Citra Aditya Bakti, Bandung.

Elli Nur Hayati, 2000. Panduan Untuk Pendamping Perempuan Korban Kekerasan, Konseling Berwawasan gender, Rifka Annisa, Yogyakarta.

F.X. Djumialdji dan Wiwoho Soejono, Perjanjian Perbururhan dan Hubungan Perburuhan Pancasila, Bina Aksara, Jakarta.

Halili Toha dan Hari Pramono, Hubungan Kerja Antara majikan Dan buruh, Rieneka Aksara, Jakarta.

Lalu Husni, 2000. Pengantar Hukum Ketenagakerjaan Indonesia, Rajawali Pers, Jakarta.

Iman Soepomo, 1988. Hukum Perburuhan Bidang Kesehatan Kerja, PT. Pradnya Paramita, Jakarta.

Imam Soepomo, 1983. Hukum Perburuhan Undang-undang dan Peraturan, Pradnya Paramita, Jakarta.

Undang-Undang Dasar 1945

Undang-Undang Nomor 1 Tahun 1982 
Tentang Pengesahan Konvensi Wina Undang-Undang Nomor 39 Tahun 2004 Tahun 1961

Undang-Undang Nomor 13 Tahun 2003

Tentang Ketenagakerjaan Tentang Penempatan dan Perlindungan Tenaga Kerja Indonesia di Luar Negeri 